\title{
Pragmatic Solutions for Solvency Capital Requirements at Life Insurance Companies: The Case of Spain
}

\author{
Asier Garayeta $^{1}$, J. Iñaki De La Peña ${ }^{1} \&$ Iván Iturricastillo $^{2}$ \\ ${ }^{1}$ Faculty of Business Administration, University of the Basque Country (UPV/EHU), Bilbao, Spain \\ ${ }^{2}$ School of Business Administration, University of the Basque Country (UPV/EHU), Vitoria-Gasteiz, Spain \\ Correspondence: J. Iñaki De La Peña, Faculty of Business Administration, University of the Basque Country \\ (UPV/EHU). Avda. Lehendakari Agirre, 8348.015 - Bilbao, Spain. Tel: 34-94-601-3876. E-mail: \\ jinaki.delapena@ehu.es
}

Received: May 23, 2014

doi:10.5430/ijba.v5n4p39
Accepted: June 18, 2014

Online Published: July 1, 2014

URL: http://dx.doi.org/10.5430/ijba.v5n4p39

\begin{abstract}
Determining optimal capital at insurance companies is a constant requirement in all countries. In Europe this process is guided by the Solvency II Directive. There are local regulations for determining this capital, but this Directive provides a new way of integrating them. The aim of this paper is to analyse the different solutions that have been used in Spain to adapt solvency capital requirements to this compulsory Directive, in order for companies to guarantee the commitments of policyholders.

We analyse how the way in which solvency capital is calculated has changed over the past thirty years, emphasising the shift from a static approach to a dynamic one. This has meant that several modifications have had to be made in the organisational structure of organizations and in their management.
\end{abstract}

Keywords: solvency, solvency capital requirement, minimum capital requirement

\section{Introduction}

The insurance business involves taking risks in exchange for a fixed income (premiums). Policyholders must have full confidence that the institution will pay out compensation if a loss occurs (Mayorga and Mora, 2008). Costs for customers in the insurance market seem to be very high relative to other industries (Holzmüller, 2009), but it is argued that this is justified because the market is based on trust and risk protection (Herrero, 2012). To cater for this risk protection, insurance companies endow capital to cope with expected commitments: it is that capital which ensures that the entity will be able to meet its commitments.

This point is so important that the International Actuarial Association (IAA) created a working group to deal with it. The group's task was to identify the basic technical principles that should underlie the evaluation and regulation of the solvency requirements applicable to insurance companies (IAA, 2009). Moreover, in May 2002 the IASB (International Accounting Standards Board) conducted an Insurance Project in two phases and proposed a set of rules, given the complexity of the insurance business. The first phase covers IFRS (International Financial Reporting Standard) 4, and in a broader sense, IAS (International Accounting Standard) 32 and IAS 39 (IASB, 2003 a). The second phase deals with more controversial issues, such as the valuation of technical provisions (IAA, 2004), (IASB, 2003 b) at market value (IASB 2005).

The European Union (EU) is undertaking a reform of the solvency of insurance companies whose main objective is to see that the capital committed is adequate, based on the risks assumed by the company. In this paper we analyse the changes in the Solvency Capital Requirement and the Minimum Capital Requirement up to the enactment of the Solvency II Directive for life insurance. These capital amounts are absolutely necessary for insurance undertakings, as they need to be robust enough to deal with any contingencies that may arise from their business (Albarrán et al., 2011) and adapt to the current situation (Alonso, 2007b), This promotes the development of good practices and convergence towards a standard model (Linder, 2004).

This interest in the solvency of insurance companies is not a recent fad. In 1948, Campagne et al. described a method for calculating the solvency margin based on a percentage to be applied to technical provisions. Using a different approach, in 1994 Cummins et al. created a framework for the analysis of risk-based systems. Applying these 
analysis risk models, Doff, 2008 and Holzmüller, 2009 concluded that Solvency II was an appropriate law due to its sensitivity to risk, its proper calibration of the formula and its simplicity, plus the possibility of internal formulation.

At the same time the financial market has undergone its own changes, known as the Basel reforms. The two are similar in structure and focus on the same objectives, but the insurance reforms attempt to create a comprehensive framework for risk management, rather than individualised risk management (Eling, 2007).

The Solvency II project was launched in 2000 to meet these needs. Accordingly, its aim was to create a prudential framework that would more appropriately reflect the risks facing insurance undertakings (Linder \& Ronkainen, 2004). It set out to examine the progress of solvency capital requirements and then establish a solvency insurance architecture. This revision was necessary to check the trends in regulations away from arbitrary values for the funding of a solvency requirement independent of the business of the insurance company, and towards parameters related to the activity of companies.

To analyse the changes in how required capital is determined in Spanish legislation on life insurance (which is the purpose of this paper), Section 2 of the paper analyses the situation as it stood before the Solvency I life insurance directive. Section 3 examines solvency capital under that directive and Section 4 considers the changes in how these concepts are determined under Solvency II. The paper concludes with comments and a list of references.

\section{History in the Field of Life Insurance}

The first step on the path that leads to Solvency II in Spain was taken in 1973 with Directive 73/239/EEC for non-life insurance. The resulting path is shown in Figure 1.

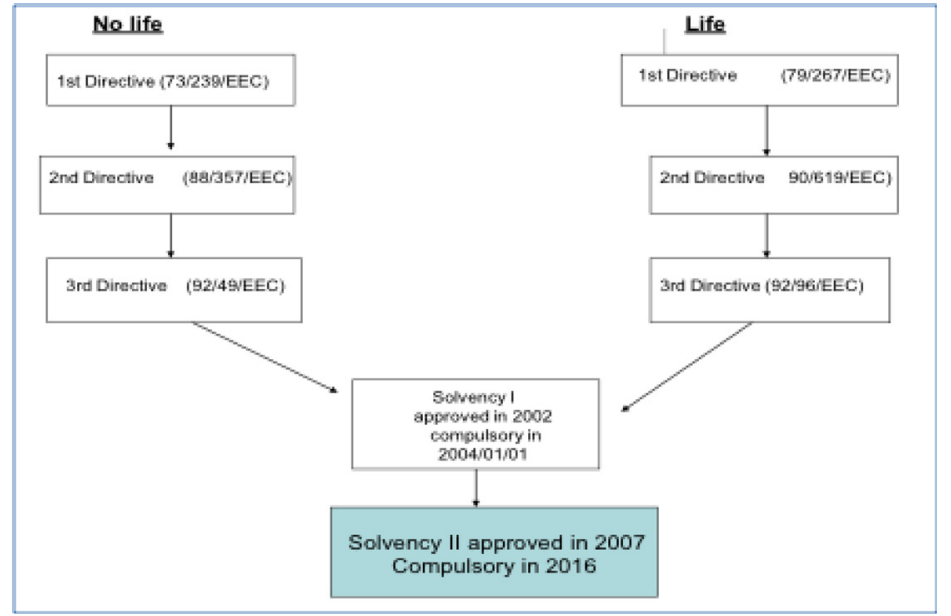

Figure 1. Trend in solvency

Source: Pilan, 2005

Solvency II is based on the Lamfalussy method (Linder and Ronkainen, 2004). As such, it establishes a set of principles subsequently adapted by provisions in order to ensure convergence towards the trend in international accounting regulations in insurance and reinsurance (UNESPA, 2006). Although nuanced, Solvency II shows the need to obtain estimates consistent with the market for assets and liabilities (White et al., 2010).

Traditionally, estimations were made using the principle of prudence, incorporating linearly stipulated technical and financial margins whose purpose was to cover potential adverse deviations in claims and cover in policies (Pozuelo, 2007). The narrowing of mediation margins in recent years implies the explicit incorporation of guarantees in the assessment of provisions (Biffis and Millossovich, 2006). Furthermore, quantification must take into account the current financial market situation as well as the technical assumptions foreseeable at the date of valuation (Barroso, 2011) (mortality, morbidity, longevity, and so on) (Moreno et al., 2008).

Obviously this point was not reached in a single year: there has been (and continues to be) a gradual process within the European Union. Each Member State already had its own laws before any Europe-wide measures were set up (Linder and Ronkainen, 2004), and it is important to see how these state laws have been converging toward legislative equality between the different Member States. In Spain, for instance, the process has been regulated by various royal decrees. Legal convergence is one of the goals of Solvency II: to establish similar frameworks in Spain and Germany, without forgetting the importance given by the regulator to policyholder protection (Sandström, 2007). 


\subsection{Directive 79/267/EEC: The First Life Directive (FLD)}

This first directive on life assurance was approved on March 5, 1979. The idea was to co-ordinate different regulations with the future goal of legislative equality between EU Member States. This was the first step towards a dynamic solvency, understood as the insurer being able to cope with current and future risks (Campagne, 1961).

Each state obliged the insurance companies in its territory to meet the minimum Solvency Margin (SM), which comprised the assets of the undertaking, free of all foreseeable liabilities, less any intangible items. The SM was thus made up of:

- The paid up Share Capital (SC) plus half the non paid-up capital

- Statutory and free reserves (not corresponding to underwriting liabilities) (RS)

- Accumulated Profit or Loss (P \& L) after deducting dividends payable (DIV).

Items related to participation in reinsurance, credit institutions, etc. were then factored in:

$$
S M=C S+R S+(P y G L-D I V)-\text { Reinsurance }
$$

This was not the only way of making the calculation. The margin was proportional to the nature and severity of risks, considering both external and internal circumstances (Willemse et al., 2006).

The guarantee fund consisted of one third of the required solvency margin, and not less than $€ 2$ million.

$$
\text { GUARANTEE FUND }=\operatorname{Max}\left(\frac{\text { SOLVENCYMARGIN }}{3} ; 2,000,000 €\right)
$$

During a company's business year its solvency margin must not fall below a minimum security level, while the guarantee fund must consist of explicit asset items. This directive enabled Member States to terminate the accumulation of activities if the interests of the insured and beneficiaries were at risk. Member States controlled the financial situation and solvency status, considering that reserves should consist of quality assets. In the calculation of the Minimum Margin of Solvency (MMS) for overall life insurance and annuities, the result was obtained by means of two addends:

$$
M M S=4 \% \cdot M R \cdot \frac{M R-R e}{M R}+0.3 \% \cdot C A \cdot \frac{C r-R e}{C r}
$$

where:

MR : Mathematical Reserves

Re : Reinsurance cessions,

CA : Capital underwritten by the company

$\mathrm{Cr}$ : Capital at risk

In addition, gross mathematical reserves were to be no less than $85 \%$ :

$$
\frac{M R-R e}{M R} \geq 85 \%
$$

And the amount of capital at risk gross of reinsurance was not to be less than $50 \%$ :

$$
\frac{C r-R e}{C r} \geq 50 \%
$$

The regulations only specified the types of assets that could form part of the margin of solvency: there were no constraints on the make-up of the remaining reserves. Given the above, it can be observed that certain parts were improvable as they were based mainly on ratios, which are not very sensitive to risk (Karp, 2007). 


\subsection{Directive 90/619/EEC: Second Life Directive (SLD)}

This Directive, dated November 8, 1990, developed the work begun by the previous directive to reduce distortions between Member States caused by differential taxation, and to create a wider market.

The legislation was focused on the authorities and their procedures, with companies considered only on a secondary level. Centred on state authorisations, information required of companies and the transfer of information between countries, it was a law focused mainly on monitoring.

\subsection{Directive 92/96/ EEC: Third Life Directive (TLD)}

This Directive, dated December 9, 1992, which was intended to deal in greater depth with the life insurance market, sets out to bring national markets towards a more integrated market, allowing Member States to impose the application of only this legislation on the companies sited within their territories. It also emphasised the composition of the solvency margin.

During this period various monitoring methods were developed. That proposed by Germany was one of the most significant (Schubert, 2007). With regard to Spain, the Insurance Regulations approved by Royal Decree 2486/1998 of 20 of November introduced new security concepts and solvency margins. This law was more flexible but no less detailed. The directive determined that:

A. life insurance should be calculated in accordance with an actuarial prospective valuation method;

B. the interest rate used in any calculation should be cautious;

C. statistical and expense elements should also be chosen prudently;

D. in profit sharing contracts the provisions could be calculated taking shares of future profits into account implicitly or explicitly;

E. provision for future expenses could be implied;

F. the method for calculating provisions could not change from year to year depending on the interests of the company.

The technical provisions were to be made up of representative assets, included in Table 1, seeking to ensure the safety, yield and liquidity of company investments.

Table 1. Representative assets, NON LIFE

\begin{tabular}{|c|c|c|}
\hline A. Investments & B. Debts and claims & C. Other assets \\
\hline $\begin{array}{l}\text {-Debt securities, bonds and other } \\
\text { money- and capital-market } \\
\text { instruments; }\end{array}$ & $\begin{array}{l}\text {-debts owed by reassurers, including } \\
\text { reassurers' shares of technical } \\
\text { provisions; }\end{array}$ & $\begin{array}{l}\text {-tangible fixed assets, other than } \\
\text { land and buildings, valued on the } \\
\text { basis of prudent amortisation }\end{array}$ \\
\hline -loans; & $\begin{array}{l}\text {-deposits with and debts owed by } \\
\text { ceding undertakings; }\end{array}$ & $\begin{array}{l}\text {-cash in bank, and in hand, } \\
\text { deposits with credit institutions }\end{array}$ \\
\hline $\begin{array}{l}\text {-shares and other variable-yield } \\
\text { instruments; }\end{array}$ & $\begin{array}{l}\text {-debts owed by policy-holders and } \\
\text { intermediaries arising out of direct }\end{array}$ & $\begin{array}{l}\text { and other bodies authorised for } \\
\text { deposits; }\end{array}$ \\
\hline -units in undertakings for collective & insurance and reinsurance operations; & -deferred acquisition costs; \\
\hline $\begin{array}{l}\text { investment in transferable securities } \\
\text { and other investment funds; }\end{array}$ & -advances against policies; & -accrued interest and rent, other \\
\hline \multirow{2}{*}{$\begin{array}{l}\text {-land, buildings and real estate } \\
\text { property rights }\end{array}$} & -tax recoveries; & ients \\
\hline & -Claims against guarantee funds. & -reversionary interests \\
\hline
\end{tabular}

- Reversible interest

Source: own work.

The fact that an assets was on the list does not mean that the Member State authorities had to allow provisions built with it. The most important standards were that assets had to be net assessed on a prudent basis, and that the only items admitted as hedges were loans if offered with sufficient guarantees, derivatives if the risk was low, transferable securities if they could be traded in the short term, etc. 
Representative assets were required to fulfil all risk diversification rules before they could be included in the technical provisions inasmuch as diversification helps avoid insolvency (Modigliani et al. 1958).

As soon as the above directives were adopted, it became noticeable that they needed to be revised. A report was therefore commissioned on calculations and minimum guaranteed amounts (Müller, 1997), on the basis that it was not advisable to begin the twenty-first century with a solvency regime designed in the 70s (Dickinson et al., 2001).

\section{Solvency I: Directive 2002/83/EEC. Solvency I Life (SIL)}

This directive is derived from prior directive 2002/12/EC, which emphasised the need for financial control and encouraged the separation of branches. That is why the creating of technical provisions was made mandatory (including mathematics). Such provisions were to be calculated with actuarial principles and prudence. The required solvency margin was also part of this treaty with its demands, list of items or index to predict future increases. Companies were made to endow provisions, which should comprise the assets listed in Directive 92/96/EEC. In Spain SIL was transposed via Act 34/2003 of 4 November, which increased the minimum levels of solvency margins, to $€ 3,000,000$ in the case of life insurers and $€ 800,000$ in the case of mutual companies.

In this case the state was able to authorise other assets that were to be included in provisions, but they were to be diversified to create the provision, and it was required that investment should not exceed:

- $10 \%$ on land or buildings

- $5 \%$ in shares and other marketable securities of a single company or loans to a single borrower.

- $5 \%$ in unsecured loans, $1 \%$ for any single unsecured loan,

- $3 \%$ in cash reserves

- and $10 \%$ in shares and bonds traded on unregulated markets

Companies were required to have a solvency margin, comprising commitment-free equity (Art. 27 SIL). This margin was different from that required in the first directive:

$$
S M=S C \pm B e+R s B e+(c p s+s l)+c s+f p r o+c g+u s c
$$

$S C \quad$ : Social Capital

$B e \quad$ : Profit or loss

RsBe : Profit reserves

Rs : Reserves

It could also comprise the following (Art.27 SIV):

- Cumulative preferential shares (cps) and subordinated loans $(s l)$ up to $50 \%$ of the margin of solvency (SM)

$$
(c p s+s l \leq 50 \% S M)
$$

- Cumulative shares (cs) up to $50 \%$ of the available solvency margin

$$
c s \leq 50 \% S M
$$

- Until December 31, 2009, an amount equal to $50 \%$ of the future profits of the company (fpro), not exceeding $25 \%$ of the available solvency margin

- $\quad$ Certain exceptional capital gains $(c g)$

- Half of the undisbursed share capital (usc), only if the amount is less than $25 \%$ of the capital stock.

The Required Solvency Margin or Minimum Solvency Required (MSR) was calculated in the same way as in the first directive, except that provisions were used instead of reserves by the use of provisions.

$$
S M=4 \% \cdot M P
$$

From the above the guarantee fund was obtained, which was one third of the solvency margin requirement and at least $€ 3$ million. This amount was revised periodically, always rounded off in multiples of 100,000.

The rules above show a simple, static model (Lozano, 2005) based mainly on accounting magnitudes that focused only on one aspect of the financial position of an entity. It was necessary to develop a dynamic model based on principles and scenarios. Nor were risks considered in their entirety or in detail. Furthermore the minimum solvency margin could create distortions and incentives for some provisions under the desirable level (KPMG, 2002). 
Solvency I was also criticised for its lack of harmonisation, on the grounds that it was oversimplified and that the application of the rules did not include full information (Trainar, 2006). To this it must be added that significant risks were excluded (CEA, 2007). Clearly, a more detailed model was needed to deal with the inefficiencies in the transparency of insurance companies in a way suited to reality. It was on this basis that Solvency II (Butt, 2007) was established.

\section{Solvency II (SII)}

4.1 Directive 2009/138/EC of November 25 on Life Insurance, Access to the Business of Insurance /Reinsurance and Its Exercise (Solvency II)

Until the enactment of this directive dated November 25, 2009, solvency was monitored by calculating ratios that had nothing to do with the current situation of companies (Alonso, 2007a). The observation of quantitative needs, requirements for own resources and especially minimum solvency capital, led to the creation of Solvency II. To implement it companies need to be transparent and provide the required information.

One of the ideas of this directive is that capital requirements should be covered by equity and assets, which insurers are allowed to use as security against obligations. For all the above the insurer is required to establish technical provisions using appropriate statistical and actuarial methods. They must always be consistent with the market, meet the standards of risk diversification, be reliable and make realistic assumptions.

The Directive sets up a standard formula for calculating the Solvency Capital Requirement, thus taking a new approach to risk. The development of Solvency II is based on three pillars (Stein, 2006) (Tarantino, 2005), as shown in Figure 2:

- Company: equity requirement (quantitative requirements).

- Administration: monitoring process (qualitative requirements).

- Market: transparency and provision of information

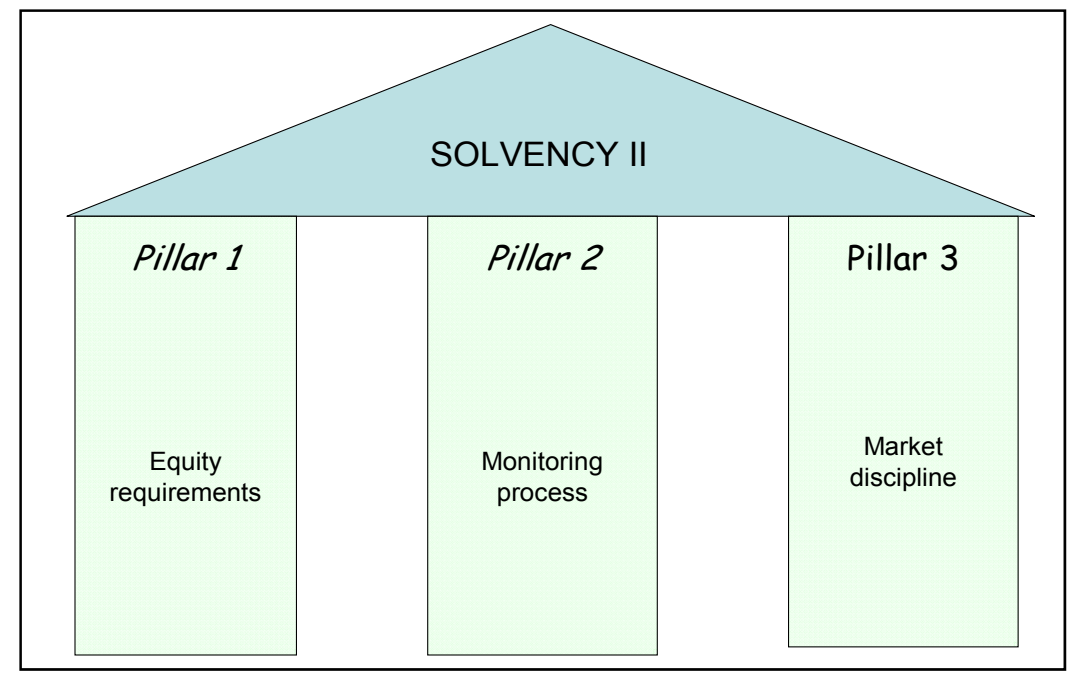

Figure 2. Three pillars of Solvency II

Source: own work

Solvency II entails a change of solvency requirements, which are based on premiums and are not a function of the market. One of the most important requirements is the programme of activity (Hernández, 2011), because it requires that the following be determined, among other things:

- the nature of risk, reinsurance and its principle;

- the equity items that constitute the minimum capital;

- administrative and financial expenditure forecasts;

- forecast balance sheet and estimations of solvency capital and minimum capital.

Insurers must establish a firm commitment to internal control by changing their organisational structure, identifying their main risks and defining each of them, by providing an assessment of acquired risks (Lozano, 2005). This 
information must be reported.

\subsection{Technical Provisions}

The technical provisions (TP) for the insurer's business must be consistent with the obligations that the company has acquired. They represent the amount that the company would have to pay if it transferred its obligations to a third party, always in keeping with financial markets in a prudent, reliable, consistent way. For greater specificity, the following is calculated separately:

$$
T P=B E+M R
$$

Where

- Best estimate (BE) is the average of future cash flows weighted by its probability, taking into account the time value of money. This requires close-to-reality, specific information (Cerchiara et al., 2008).

- Margin risk (MR) is the value which ensures that technical provisions are sufficient to meet insurance obligations. It must be determined by the capital cost method $(\mathrm{CoC})$. As far as equity is concerned:

$$
\text { Own funds (Art.87 SII) }=B O F+A O F
$$

- Basic own funds (BOF) is the excess of assets over liabilities and subordinated liabilities

- Additional own funds (AOF) means funds other than basic funds that may be required to absorb losses. Supervisors must authorise the way in which this amount is calculated and the amount covered, based on prudent, realistic assumptions, usually using face value.

\subsection{Solvency Capital Required (SCR)}

This is the capital that an insurance company needs to deal with unforeseen situations. It must be calculated based on the profile of the insurer regarding exposure to risk. It must therefore include risks affecting the insurance company (technical risk, operational, investment, credit and liquidity) calculated in a modular way, so risks are calculated similarly but with a different method (Sanström, 2007b).

Within Equity there must be a part that covers the Solvency Capital Required (SCR) if necessary. Two ways to calculate this are proposed: a standard formula or an internal model. Some studies on this point assert that the standard formula does not always meet the required hypothesis (Devineu and Loisel, 2009) and fails to clarify the correlations between different risks (Pozuelo, 2007). There are also several approaches, with formulae based on factors, scenario simulation, etc (CEIOPS, 2011).

The most important advantages of the standard formula are its simplicity and its economy of means. Internal model must be approved by supervisor before its implementation. The stand-out advantages of an internal model include the fact that it measures risks according to the true experience of the company (Santomil et al 2011.), provides a basis for effective risk management and enables the efficiency of risk mitigators to be assessed (EC, 2003) (Rokainen et al 2007).

There are also two possible approaches to internal models: bottom up and top down (Albarrán et al 2010.).Internal models are not new, as they are the continuation of profit testing methods that have been in use since 1980 (Liebwein, 2007).

The calculation of SCR must be equal to the value at risk of the basic own funds of the insurance or reinsurance undertaking, subject to a confidence level of $99.5 \%$ and a horizon of one year. This capital has to cover the different risks, such as underwriting, credit, market and operational risks among others. The VaR could be used as a measurement in the case of operational risk (Hernández et al., 2012). However the aforesaid standard formula based on asymmetry and correlation may not be sufficient to meet the objectives pursued by Solvency II (Pfeifer et al., 2008).

This calculation must be performed at least once a year. The process of the standard formula (Art.103 SII) is as follows:

$$
S C R=S C R_{\text {basic }}+S C R_{\text {operacional risk }}+A A
$$

where

A. $S C R_{\text {basic }}$ : Using the formula in Annex IV of SII, underwriting risks, market risk and the counterparty risk module are analysed. The parameters of the standard formula may be replaced by specific parameters, provided that the authority allows this. But the legislation provides that the modules should consist of the following factors: 


$$
S C R_{\text {basic }}=\sqrt{\sum_{i j} \operatorname{Corr}_{i j} \times S C R_{i} \times S C R_{j}}
$$

i) Underwriting risk module (Art.105 SII):

- Life insurance: mortality risk, longevity, etc.

$$
S C R_{\text {life }}=\sqrt{\sum_{i j} \operatorname{Corr}_{i j} \times S C R_{i} \times S C R_{j}}
$$

- Health insurance: risks from volatility, risk premium, etc.

ii) Market risk Module: due to the volatility of markets. It should include the capital for interest rate risk, equity, etc.

$$
S C R_{\text {market }}=\sqrt{\sum_{i j} \operatorname{Corr}_{i j} \times S C R_{i} \times S C R_{j}}
$$

iii) Counterparty risk module

B. Operational $S C R_{\text {risk: }}$ This includes risks not included in the previous section. For life insurance the amount of expenses incurred must be taken annually.

C. Amount of adjustment: This refers to the loss absorption capacity of technical provisions and deferred taxes (Art.108 SII).

Besides the general formula there is the possibility of a company developing full (if they refer to all risks) or partial (when they only involve some risk) internal models (Santomil et al 2011), though such models are expensive and complex (Eling et al. 2007).

The supervisor will test internal models and check their use, taking their limitations into account (Vaughan, 2009). It will also be verified that both the model and the probability distribution are based on appropriate actuarial / statistical techniques, using reliable and current information and realistic assumptions. These internal models are usually more oriented towards the risk profile than the required capital (Berglund, 2006).

\subsection{Minimum Capital Required (MCR)}

MCR is the amount below which the operations of the insurer become an unacceptable risk to the insured. It must be formed clearly and simply by admissible basic funds, must be obtained with a $85 \%$ confidence in one year and calculated quarterly. There is a minimum of $€ 2,200,000$ in classes other than life and $€ 3.2$ million for the field of life. The figure must be between $25 \%$ and $45 \%$ of the Solvency Capital Required (SCR).

To achieve the above, the insurer must invest its assets under the principle of caution, investing only in assets whose risks it can identify, measure, monitor, manage and evaluate.

Solvency II considers available capital as the difference between the market value of assets and liabilities. If there is no quotation price, consistent market valuation must be used, as occurs with technical provisions. 


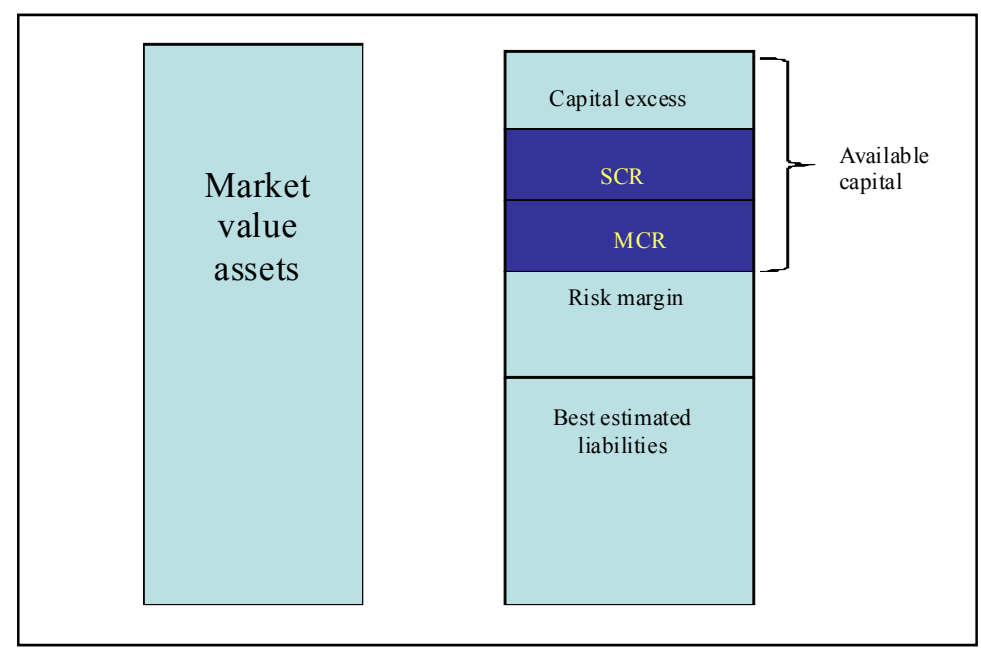

Figure 3. Minimum capital requirement and capital solvency requirements

Source: Pozuelo, 2008; own work

Two levels of minimum demanded own funds are also provided. First the MCR and above it the SCR (financial capital) are set. There are then compared with the available capital based on the balance sheet to determine the excess available capital that is available to the insurance company and its shareholders. This capital is not committed to the business and greater value for the undertaking is derived from its maximisation (Eisele and Artzner, 2010). This two-fold requirement structure is more stable than a single condition (Sijben, 2002).

Regarding the valuation of assets and liabilities at market value, there may be assets whose value is zero (Alonso, 2007). The reason why liabilities are valued at market prices is to improve consistency and transparency, and to make the capital market more efficient (Kaliva et al., 2007).

Table 2. Assets and Liabilities versus their ratings

\begin{tabular}{lcc}
\hline & TYPE & VALUATION \\
\hline \multirow{2}{*}{ Assets } & Traded in liquid markets & Market value \\
& Liquid assets & Market information value \\
& High depreciation assets & Zero value \\
\hline \multirow{2}{*}{ Liabilities } & Associated with hedgeable risks & Market value of hedges \\
& Associated with non hedgeable risks & BE + MR \\
\hline
\end{tabular}

Source: Alonso, 2007.

The path to the final Solvency II Directive has been a long one (Doff, 2008). It has been developed with the QIS (Quantitative Impact Study) performed by the CEIOPS (Committee of European Insurance and Occupational Pensions Supervisors). This path to Solvency II is illustrated in Figure 4. 


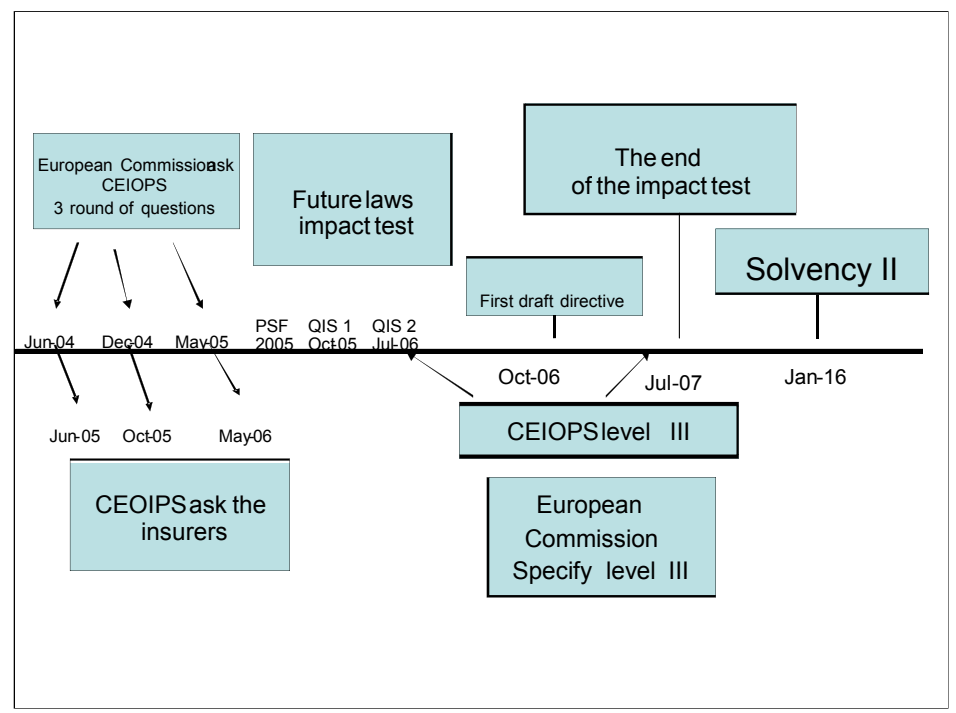

Figure 4. Solvency II time frame

Source: Pilan, 2005

\section{Summary and Concluding Remarks}

There have been changes in companies, in their internal administration based on risk management and decision making. Moreover, companies have come to be monitored quarterly: this provides greater protection for the insured as it is more likely to follow deviations. In addition in Spain a system needs to be established to speed up the information transfer process, as there is a danger of bureaucratising the process.

The inclusion of the MCR and SCR entails greater transparency, because the resulting two levels of requirements will result in more solvent companies.

The regulations prior to Solvency II were based on a simple, static model. They included accounting information but not financial information in the face of potential future contingencies. This shift involves changes in methods and philosophy, from a bureaucratic structure to comprehensive risk management within companies. And that means a change in organisational structure and requires the development of balanced scorecards for decision-making. Flexibility is always required when the risk management model is created, since the same model cannot be adapted to all situations. This reduces the systemic risk that would exist if the same model were applied to all businesses. It must be taken into account that a complicated model does not ensure that the best data will be obtained, and this should be considered in the development of internal models.

\section{Acknowledgements}

Financial support from UFI 11/51 Dirección Empresarial y Gobernanza Territorial y Social de la UPV/EHU is gratefully acknowledged.

\section{References}

73/239/EEC. First Council Directive of 24 July 1973.

79/267/EEC. First Council Directive of 5 March 1979. (FLD).

90/619/EEC. Council Directive of 8 November 1990. (SLD).

92/96/EEC. Council Directive of 10 November 1992. (TLD).

Insurance Regulation approved by R. D. 2486/1998, of 20 November.

2002/12/EC. Directive of the European Parliament and of the Council of 5 March 2002.

2002/83/EC. Directive of the European Parliament of 5 November 2002 (Solvency I or SIL).

34/2003 Law of November 4, of modification and adaptation to EU rules of private insurance legislation.

2009/138/EC. Directive of the European Parliament and of the Council of 25 November 2009 (Solvency II or SII).

Albarrán, I., Alonso, P., \& Camino, D. (2011). Insurance Regulation and Business Profiles: Organizational form and Solvency Risk. 4th Workshop on Risk Management and Insurance. Sevilla. 
Albarrán Lozano, I., \& Alonso González, P. (2010). Métodos estocásticos de estimación de las provisiones técnicas en el marco de Solvencia II. Fundación MAPFRE, Instituto de Ciencias del Seguro, pp. 15-32.

Alonso González P. (2007a). Solvencia II o el riesgo como eje central. Actuarios nº 26, julio 2007, 27-29.7.

Alonso González P. (2007b). Solvencia II: ejes del proyecto y diferencias con Basilea II. Anales del Instituto de Actuarios Españoles, (13), 37-56.

Berglund Raoul, K. L., \& Ronkainen, V. (2007). Aspects on calculating the Solvency Capital Requirement with the use of internal models. Afir colloquio. Paris.

Biffis, E., \& Millossovich., P. (2006). The fair value of guaranteed annuity options. Scandinavian Actuarial Journal, 1. http://dx.doi.org/10.1080/03461230500462204

Blanco-Morales, Guillén Estany, M., \& Domínguez Fabián, I. (2010). Estudio sobre el sector asegurador en España 2010. Fundación de Estudios Financieros.

Butt, M. (2007). Insurance, Finance, Solvency II and Financial Market Interaction. The Geneva Papers on Risk and Insurance Issues and Practice, 32, 42-45. http://dx.doi.org/10.1057/palgrave.gpp.2510115

Campagne, C. (1961). Minimum standards of solvency for insurance firms. Report to the OECD. 11th March, $\mathrm{TFD} / \mathrm{PC} / 565$.

Campagne, C., Van der Loo, \& Yntema, A.J. (1948). Contribution to the method of calculating the stabilization reserve in life assurance business. Gedenkboek Verzekeringskamer 1923- 1948, Staatsdrukkerij- en uitgeverijbedrijf, Den Haag, pp. 338-378

Cerchiara, R. R., Matthew, E., \& Gambini, A. (2008). Generalized linear models in life insurance: Decrements and risk factor analysis under Solvency II. AFIR .Colloquio Roma

Comité Europeo de los Seguros (CEA). (2007). Solvency II: Main results of CEA's impact assessment. CEA. June. pp. 1-28.

Cummins, J.D., Harrington, S., \& Niehaus, G. (1994). An economic overview of risk-based capital requirements for the property-liability insurance industry. Journal of Insurance Regulation, 11, 427-447.

Devineu, L., \& Loisel, S. (2009). Risk aggregation in Solvency II: How to converge the approaches of the internal models and those of the standard formula? Bulletin Français d'Actuariat, 18(9), 107-145.

Dickinson, G.M., Dinenis, E., \& Siokis, V. (2001). Rethinking Solvency Margin in Europe. Insurance research and Practice, 16, Part 1, 34-46.

Doff, R. (2008). A critical analysis of the Solvency II proposal. Geneva Papers on Risk and Insurance: Issues and Practice, 32(3), 193-206. http://dx.doi.org/10.1057/gpp.2008.2

Eisele, K-T., \& Artzner, P. (2010). Supervisory Insurance Accounting. Mathematics for provision and solvency capital requirements. Astin Bulletin. http://dx.doi.org/10.2143/AST.40.2.2061128

Eling, M., Schmeiser, H., \& Schmit, J. T. (2007). The Solvency II Process: Overview and Critical Analysis. Risk Management \& Insurance Review Journal, 70-75. http://dx.doi.org/10.1111/j.1540-6296.2007.00106.x

EUROPEAN COMMISSION. (2003). Solvency II - Reflections on the General Outline of a Framework Directive and Mandates for Further Technical Work. Note to the IC Solvency Subcommittee MARKT/2539/03.

Hernández Barros, R., \& Martínez Torre-enciso, M. I. (2012). Capital assessment of operational risk for the solvency of health insurance companies. Journal of operational risk, 7, 43-65.

Hernández, R. (2011). Metodología Financiera de gestión y cuantificación de riesgos de las entidades aseguradoras. Pecunis, 81-106.

Herrero, A.B. (2012). Riesgo Operacional en el marco de Solvencia II. Ed. Mapfre.

Holzmüller, I. (2009). The United States RBC Standards, Solvency II and the Swiss Solvency Test: A Comparative Assessment. The Geneva Papers on Risk and Insurance Issues and Practice, 34, 56-77. http://dx.doi.org/10.1057/gpp.2008.43

IAA. (2004). Changes in Accounting Policy while under International Financial Reporting Standards. International Actuarial Association.

IAA. (2009). A global framework for insurer Solvency Assesment-Un marco global para la evaluación de la 
solvencia del asegurador. Trad. Mayoral, Rosa; Moreno, Rafael y Dan Lerner, Andrés. International Actuarial Association.

IASB. (2003a). Financial Instruments: Recognition and Measurement. December. International Accounting Standard 39

IASB. (2003b). Fair value hedge accounting for a portfolio hedge of interest rate risk. Exposure draft of proposed Amendment to IAS 39 Financial Instruments: Recognition and Measurement.

IASB. (2005). The fair value option. Amendment to IAS 39 Financial Instruments: Recognition and Measurement, June.

Kaliva, K., Koskinen L., \& Ronkainen, V. (2007). Internal models and arbitrage-free calibration. AFIR Colloquio Stockholm.

Karp, T. (2007). International Solvency Requirements - Towards more Risk-based Regimes. The Geneva Papers on Risk and Insurance Issues and Practice, 32, 367-381. http://dx.doi.org/10.1057/palgrave.gpp.2510139

KPMG. (2002). Study into the methodologies to assess the overall financial position of an insurance undertaking from the perspective of prudential supervision. Prepared for the European Commission.

Liebwein, P. (2006). Risk Models for Capital Adequacy: Applications in the Context of Solvency II and Beyond. The Geneva Papers on Risk and Insurance Issues and Practice, 31, 528-550. http://dx.doi.org/10.1057/palgrave.gpp.2510095

Linder, U., \& Ronkainen, V. (2004). Solvency II - towards a new insurance supervisory system in the EU. Scandinavian Actuarial Journal, 6, 462-474. http://dx.doi.org/10.1080/03461230410000574

Lozano Aragüés, R. (2005). Las implicaciones de Solvencia II en el sector asegurador español. Estabilidad financiera, (9), 59-70.

Mayorga, M.C., \& Mora, P. (2008). Protección al cliente en los contratos bancarios y de seguros. Cuadernos de Ciencias Económicas y Empresariales, 36, 23-42. Universidad de Málaga.

Modigliani, F., \& Miller M. (1958). The cost of capital, corporate finance, and the theory of investment. American Economic Review, 48, 655-669.

Moreno, R., Mayoral, R., Leiner, A.D., \& Trigo, E. (2008). Una Introducción al nuevo marco para la evaluación de la solvencia de la entidad aseguradora. Cuadernos de Ciencias Económicas y Empresariales, 36, 59-74. Universidad de Málaga.

Müller, H. (1997). Solvency of Insurance Undertakings. Report of The Conference of Insurance Supervisory Authorities of the member states of European Union.

Pfeifer, D., \& Strassburger, D. (2008). Solvency II: stability problems with the SCR aggregation formula. Scandinavian Actuarial Journal, 1, 61-77. http://dx.doi.org/10.1080/03461230701766825

Pilán Canorea, O. (2005). Reforma del Control de la Solvencia de la Empresa de Seguros en la UE: Solvencia II. Programa de Doctorado en Economía Financiera, Actuarial y Matemática. Universidad Complutense de Madrid.

Pozuelo De Gracia, E. (2007). El Fair Value de las Provisiones Técnicas de Seguros de Vida. Instituto de Ciencias del Seguro. Fundación Mapfre.

Pozuelo De Gracia, E. (2008). Solvencia II: Capital Económico en Aseguradoras. Revista Economía financiera, (16), $3^{\circ}$ cuatrimestre.

Ronkainen, V., Koskinen, L., \& Berglund, R. (2007). Topical modelling issues in Solvency II. Scandinavian Actuarial Journal, 2007, 135-146. http://dx.doi.org/10.1080/03461230701257098

Sandström, A. (2007). Solvency - a historical review and some pragmatic solutions. Bulletin Swiss Association of Actuaries, (1), 11-33.

Sandström, A. (2007b). Solvency II: Calibration for skewness. Scandinavian Actuarial Journal, 2, 126-134 http://dx.doi.org/10.1080/03461230701250481

Santomil, D., Otero, L.A., Fernández, S., \& Vinel, M. (2011). Análisis del riesgo de renta variable en el marco de solvencia II: Modelos internos frente a modelo estándar. Cuadernos de Economía y Dirección de la Empresa, 14(2), 91-100. http://dx.doi.org/10.1016/j.cede.2011.02.003

Schubert, T., \& Grießmann, G. (2007). German Proposal for a Standard Approach for Solvency II. The Geneva 
Papers on Risk and Insurance Issues and Practice, 32, 133-150. http://dx.doi.org/10.1057/palgrave.gpp.2510116

Sijben, J.J. (2002). Regullation versus market discipline in banking supervision: An overview - part 2. Journal of International Banking Regulatio, 4, 55-71. http://dx.doi.org/10.1057/palgrave.jbr.234013

Stein, R. W. (2006). Are you ready for Solvency II?. Bests review, 106(11), 88.

Tarantino, A. (2005). Globalization efforts to improve internal controls. Accounting Today, 19(11), 37.

Trainar, P. (2006). The Challenge of Solvency Reform for European Insurers. The Geneva Papers on Risk and Insurance Issues and Practice, 31, 169-185. http://dx.doi.org/10.1057/palgrave.gpp.251006

UNESPA. (2006). Solvencia II: más cerca de lo que parece. Jornada Internacional. Madrid.

Vaughan, T. M. (2009). The Implications of Solvency II for U.S. Insurance Regulation. Networks Financial Institute Policy Brief: No. 2009-PB-0.

Willemse, W.J., \& Wolthuis, H. (2006). Risk Bases solvency and their validity. AFIR/ERM. Paris colloquium. 